\title{
The Use of Clinical PBL in Primary Care in Undergraduate Medical Schools
}

\section{Aplicação do PBL Clínico na Atenção Primária em Cursos de Medicina}

\section{KEYWORDS}

- Problem-Based Learning.

- Primary Health Care.

- Clinical Clerkship.

- Teaching.

- Perception.

- Medical Students.

- Undergraduate Medical Education.

- Medical Education.

\author{
Gustavo Salata Romão ${ }^{I}(\mathbb{D})$ \\ Reinaldo Bulgarelli Bestetti $i^{I}$ (D) \\ Lucélio Bernardes Couto ${ }^{I}(\mathbb{D}$
}

\begin{abstract}
Introduction: Problem-based learning (PBL) is a collaborative student-centered learning method for small groups, based on the mobilization of previous knowledge and on critical reasoning for problem solving. Although it has been used predominantly in the classroom, when applied in clinical studies, PBL can increase the intrinsic motivation and long-term knowledge retention. In addition, Clinical PBL represents a more effective option to learn from practice considering the students' overload in clinical clerkships in the Unified Health System (UHS). This study aimed to assess the students' perception of a Clinical PBL model implemented in Primary Health Care (PHC) clerkships during the first four years of the Medical Course at the University of Ribeirão Preto (UNAERP) in 2017. Method: The primary outcome was assessed by the DREEM (Dundee Ready Educational Environment Measure) tool, which contains 50 items distributed in five dimensions. The questionnaire was applied to 374 medical students, corresponding to $78 \%$ of the total number of medical students from the first to the fourth year. Results: For most of the evaluated items, the students' perceptions were "positive", including the dimensions "Perception of Teachers", "Perception of Academic Results" and "Perception of the General Environment". For the dimensions "Perception of Learning" and "Perception of Social Relationships" the evaluation was "more positive than negative". The DREEM total score was 124.31, corresponding to $62.15 \%$ of the maximum score, which indicates a perception that is "more positive than negative" regarding the Clinical PBL. The internal consistency given by Cronbach's alpha was 0.92. Conclusion: The use of Clinical PBL in PHC qualifies learning from practice, is well accepted by medical students and offers a useful option to the students' overload in the clinical clerkship during the first four years of the Medical School.
\end{abstract}




\section{PALAVRAS-CHAVE}

- Aprendizagem Baseada em Problemas.

- Atenção Primária à Saúde.

- Estágio Clínico.

- Ensino.

- Percepção.

- Estudantes de Medicina.

- Educação de Graduação em Medicina.

- Educação Médica.

Received on $4 / 26 / 20$

Accepted on $8 / 31 / 20$

\section{INTRODUCTION}

Problem-based learning (PBL) is a collaborative student-centered learning method for small groups and based on constructivist and hypothetico-deductive theories ${ }^{1}$. Described by Neufeld e Barrows ${ }^{2}$ in 1974, and applied for the first time at McMaster University, the PBL conception was based on the students' disappointment in the presence of a fragmented medical training and a growing overload of scientific information not applicable to clinical practice ${ }^{3}$. For Barrows, the teaching of medicine should be based on clinical reasoning and on the solution of authentic medical problems, instead of presenting out-of-practical context and discipline-based information ${ }^{3,4}$.

In PBL, problem situations are presented and discussed in small groups of 8 to 10 students under the supervision of a facilitator, whose main role is to promote interactions and involve students in the entire learning process ${ }^{5}$. The seven classic steps described by Henk Schmidt for the PBL method are: the clarification of unknown terms (1), the identification of problems (2) and their discussion based on previous knowledge (3), the summary and the hypotheses generated from the discussion (4), the creation of learning objectives based on knowledge gaps (5), the search for information through self-directed study (6) and rediscussing the case by the integration of new knowledge (7). In the first meeting (or opening session) the problem situation is presented, and the first five steps are developed. In the second meeting (or closing session), which takes place after the self-directed study, the seventh step is developed. Problem situations can correspond to clinical cases ${ }^{3}$ or biomedical phenomena ${ }^{5}$.

PBL is traditionally restricted to classrooms and the initial years of courses, using fictitious clinical cases, with few reports of its use in the discussion of the treatment of real patients. ${ }^{6}$. To favor the use of this methodology in clinical teaching, several adaptations have been described in the world literature, with Clinical PBL being one of them. According to

\section{RESUMO}

Introdução: A aprendizagem baseada em problemas (do inglês problem-based learning - $P B L$ ) é um método de aprendizagem colaborativa para pequenos grupos, centrado no estudante, fundamentado na mobilização de conhecimentos prévios e no raciocínio crítico para a solução de problemas. Embora tenha sido utilizado predominantemente em sala de aula, quando aplicado em estágios clínicos, o PBL pode aumentar a motivação intrínseca e a retenção de conhecimento em longo prazo pelos estudantes. Além disso, o PBL clínico pode representar uma opção mais efetiva de aprendizado a partir da prática ante a sobrecarga de alunos nos estágios clínicos no Sistema Único de Saúde. Este estudo teve por objetivo avaliar a percepção dos estudantes sobre um modelo de PBL clínico implementado em estágios de atenção primária à saúde (APS) no pré-internato do curso de Medicina da Universidade de Ribeirão Preto (Unaerp) em 2017. Método: O desfecho primário foi avaliado por meio do instrumento Dundee Ready Educational Environment Measure (DREEM), que contém 50 itens distribuídos em cinco dimensões. O questionário foi aplicado a 374 alunos de Medicina que corespondem a 78\% do total de estudantes do pré-internato. Resultados: Para a maioria dos itens avaliados, acadêmicos" e "percepção do ambiente geral". Para as dimensões "percepção da aprendizagem" e "percepção das relações sociais", a avaliação foi "mais positiva do que negativa". O escore total das respostas foi de 124,31, correspondendo a 62,15\% do escore máximo, o que indica uma percepção "mais positiva do que negativa" sobre a atividade. A consistência interna dada pelo alfa de Cronbach foi de 0,92. Conclusão: $O$ uso do PBL clínico em APS qualifica o aprendizado a partir da prática, é bem-aceito pelos estudantes de Medicina e oferece uma opção viável à sobrecarga de alunos em estágios clínicos do pré-internato. 
Preto (UNAERP). In view of the students' positive perception about the activity, the course teachers and managers were consulted about the possibility of implementing this strategy in clinical clerkships in PHC in the pre-internship period ${ }^{9}$. The proposal was approved by all and from a curricular reform, the Clinical PBL was implemented in the UNAERP Medical School in 2017.

This study aimed at assessing the perceptions of medical students about the use of Clinical PBL in PHC, as well as to evaluate the applicability, advantages, and limitations of using this strategy.

\section{METHODS}

This is an impact assessment study of an educational intervention (Clinical PBL), in PHC Teaching in the UNAERP Medical School, carried out between January and March 2018, of which Research Project was submitted to and approved by the Ethics Committee in Research by UNAERP, CIEE $n^{\circ}:$ 67795717.9.0000.5498.

\section{Context}

In the UNAERP Medical School, the PBL method has been used since 2002 for the cognitive learning of students in the pre-internship period $^{10}$. The PHC Teaching Module is developed in the seven initial semesters (first to seventh stages) of the UNAERP Medical School, with a total workload of 742 hours, distributed between practical and theoretical-practical activities in small groups of 8 to 10 students. Throughout the seven stages, students are placed in environments of PHC professional practice that include households, Basic Health Units (BHUs) and Family Health Units (FHUs), where they carry out activities at increasing levels of complexity under the supervision of teachers. In the first, second, third and fourth stages, home visits (HV) are carried out with an emphasis on environmental health, adult health, child health and woman health, respectively. In the several micro areas, the HV are supported by community health agents. In the fifth, sixth and seventh stages, individual consultations are performed in offices at the BHUs and FHUs with an emphasis on adult health, mental health and women's health, respectively ${ }^{10}$.

\section{Educational intervention}

In February 2017, the final model of the Clinical PBL was implemented in PHC Teaching from the first to the seventh stages of the UNAERP Medical Course. To obtain meaningful learning from practice, the Clinical PBL was structured so that the discussions were based on the treatments and HV performed by the students. In parallel with the activities developed at BHUs and FHUs, the opening and closing sessions of the Clinical PBL are held in classrooms at the university, with the same groups of 8 to 10 students working in practical scenarios, under the supervision of a facilitating teacher. The opening session follows the first five classic steps of the PBL, and the discussion trigger elements correspond to the treatments and HV records made by the students themselves. In each opening session, the report or record of at least one treatment or HV performed by 2 to 3 students is presented, so that, at the end of the academic semester, all students in a small group have presented and discussed at least one of the cases clinical or HV that they follow in the practical environment. At the end of this session, knowledge gaps are identified and learning objectives are established.
After a period of one to two weeks of self-directed study, students return for the closing session under the supervision of the same facilitator. This second session begins with the application of a multiple-choice test to verify the knowledge acquired about the learning objectives (pre-test). Next, a small group discussion takes place so that students share the new knowledge among themselves, which corresponds to the seventh stage of the PBL. At the end of the session, clinical cases or HV are presented again, health needs are identified, and a care plan is established for each case, in the light of the new knowledge. The latter corresponds to the eighth stage, added by us to the PBL, for its better adaptation to clinical use. In the week following the closing session, students return to the BHUs and FHUs and the care plan produced is discussed with the local health team to be later applied for the benefit of patients and families. Each pedagogical cycle of the Clinical PBL includes an initial care or HV in the practice environments, an opening session, a closing session, and a return care or $\mathrm{HV}$, in which the care plan will be applied. During each academic semester, two or three pedagogical cycles of the Clinical PBL are developed. For the evaluation of students in the pedagogical cycles of the Clinical PBL, attitude and interest during consultations and HV, the quality of the reports and records presented, participation in the opening and closing sessions and performance in the pre-tests are taken into account. All teachers involved in this activity were trained in the PBL method before the beginning of the school semester.

Study sample and population

The study population included 480 students regularly enrolled in the first to the seventh semesters of the UNAERP Medical Course in January 2018, one year after the implementation of the Clinical PBL in PHC. A non-probabilistic sampling of convenience was used, and everyone was invited to participate. The invitation was made by the teachers during the presentation of the academic semester and the inclusion in the study was attained when the participants signed the Free and Informed Consent (FIC) form. Students who were not enrolled in the PHC Teaching module, those who were absent on the day the FIC was filled out, and those who did not freely agree to participate were excluded from the study.

\section{Assessment of students' perception}

The perception of medical students about the use of Clinical PBL in PHC was assessed by applying the validated Portuguese version of the DREEM (Dundee Ready Educational Environment Measure) questionnaire $^{11}$. The DREEM questionnaire is internationally recognized as a valid and reliable instrument to assess medical students' perceptions of educational environments ${ }^{12-14}$. It has been used to assess the impact of new interventions on these environments, allowing the identification of positive aspects and weaknesses through structured feedback ${ }^{15}$. Additionally, it allows the standardized analysis between different activities and scenarios ${ }^{15}$. The instrument consists of 50 items that assess five dimensions related to the educational environment: perception of learning (12 items), perception of teachers (11 items), perception of academic results (8 items), perception of the general environment (12 items) and perception of social relationships (7 items). Each item is assessed on a five-point Likert scale, with " $0=$ fully disagree", "1 = partially disagree", " 2 = neither agree nor disagree”, “3 = partially agree" and " 4 = fully agree". There are nine negative items, of which scores should be analyzed in reverse ${ }^{13}$.

REVISTA BRASILEIRA DE EDUCAÇÃO MÉDICA

3 44 (4) : e143; 2020 


\section{Analysis procedures}

The analysis of the results was based on the average score for each item, the sum of the scores for each dimension and the total score of the instrument. For the individual analysis of the individual items, the average score $\geq 3.5$ was considered highly satisfactory, between 2 and 3.5 , satisfactory and $\leq 2.0$, unsatisfactory ${ }^{16}$. For the purposes of results presentation and analysis, the scores on the negative items $(4,8,9,17,25$, $35,39,48$ and 50) were inverted.

The sum of the scores obtained in each dimension was analyzed according to the criteria used by Jiffry, McAleer et al. ${ }^{17}$. The total score obtained at the instrument application was analyzed according to Edgreb, Haffling et al. ${ }^{18}$ in relation to the maximum value of 200 , and the more the score of an activity approaches this value, the more positive is its perception ${ }^{18}$.

The internal consistency was analyzed using Cronbach's alpha coefficient, considering acceptable values between 0.7 and 0.95 for reliability ${ }^{19}$.

\section{RESULTS}

Of the 480 recruited students, 374 (78\%) answered the DREEM questionnaire. The mean age of the respondents was 21.7 years, 242 $(64.7 \%)$ of which were females, with representatives from all semesters of the medical course.

Table 1 shows the average scores of the items for the "learning perception" dimension. The scores for items 25 and 48 were reversed. According to the established criteria, the students' perception was "satisfactory" for most items of this dimension, except for items 7, 20 and 24, of which perception was "unsatisfactory". Among the positive aspects, it is worth noting the fact that the methodology is centered on the student (2.54) and not on the teacher (2.74), with the purpose of developing skills (2.30) and self-confidence (2.08) through self-learning (2.28) and continuing education (2.38). The objectives are clear (2.11) and students are encouraged to participate in the activities (2.26). Some aspects suggested attention and improvements such as the fact that the activity is not always stimulating (1.69), cohesive and focused (1.72) and the time allocated to it is not always well used (1.45). The total score in this dimension was 25.6 of a maximum of 48 . According to the established criteria, the students' perception of the "learning perception" dimension was "more positive than negative".

Table 2 shows the average scores of the items for the "teachers' perception" dimension. The scores for items 8, 9, 39 and 50 were inverted. According to the established criteria, the students' perception was "satisfactory" for all items of this dimension. Some aspects deserve to be highlighted, especially those related to the faculty profile and attitude. According to the students' perceptions, teachers are respectful and attentive to students (3.14) and patient (3.27), with whom they establish good communication (3.22). They are sufficiently prepared and trained for the development of activities (2.70), making it possible to understand their role (2.45). They facilitate and supervise activities in a serene (2.84) and balanced (2.88) manner, providing qualified feedback (2.72) and constructive criticism to students (2.75). The total score in this dimension was 31.3 of a maximum of 44 . According to the established criteria, the students 'perception of the dimension "teachers' perception" was "positive”.

Table 3 shows the average scores of the items for the dimension "perception of academic results". According to the established criteria, the students' perception was "satisfactory" for all items of this dimension.

\begin{tabular}{|c|c|c|}
\hline \multirow{2}{*}{\multicolumn{3}{|c|}{$\begin{array}{l}\text { Table } 1 \\
\text { Score of items in the "Learning Perception" dimension of the } \\
\text { DREEM questionnaire }\end{array}$}} \\
\hline & & \\
\hline Order & Item & Score \\
\hline 1. & I am encouraged to participate in class & 2.26 \\
\hline 7. & The teaching is often stimulating & 1.69 \\
\hline 13. & The teaching is student-centered & 2.54 \\
\hline 16. & $\begin{array}{l}\text { The teaching is sufficiently concerned to develop } \\
\text { my competence }\end{array}$ & 2.30 \\
\hline 20. & The teaching is well focused & 1.72 \\
\hline 22. & $\begin{array}{l}\text { The teaching sufficient concerned to develop my } \\
\text { confidence }\end{array}$ & 2.08 \\
\hline 24. & The teaching time is put to good use & 1.45 \\
\hline 25. & The teaching over-emphasizes factual learning & 2.05 \\
\hline 38. & $\begin{array}{l}\text { I am clear about the learning objectives of the } \\
\text { course }\end{array}$ & 2.11 \\
\hline 44. & $\begin{array}{c}\text { The teaching encourages me to be an active } \\
\text { learner }\end{array}$ & 2.28 \\
\hline 47. & $\begin{array}{l}\text { Long-term learning is emphasized over short } \\
\text { term }\end{array}$ & 2.38 \\
\hline 48. & The teaching is too teacher-centered & 2.74 \\
\hline & Obtained Score & 25.6 \\
\hline
\end{tabular}

Source: The authors.

\begin{tabular}{|c|c|c|}
\hline \multirow{2}{*}{\multicolumn{3}{|c|}{$\begin{array}{c}\text { Table } 2 \\
\text { Score of items in the "Teachers' Perception" dimension of the } \\
\text { DREEM questionnaire }\end{array}$}} \\
\hline & & \\
\hline Order & Item & Score \\
\hline 2. & The teachers are knowledgeable & 2.45 \\
\hline 6. & The teachers are patient with patients & 3.27 \\
\hline 8. & The teachers ridicule the students & 3.14 \\
\hline 9. & The teachers are authoritarian & 2.84 \\
\hline 18. & $\begin{array}{l}\text { The teachers have good communications skills } \\
\text { with patients }\end{array}$ & 3.22 \\
\hline 29. & $\begin{array}{c}\text { The teachers are good at providing feedback to } \\
\text { students }\end{array}$ & 2.72 \\
\hline 32. & The teachers provide constructive criticism here & 2.75 \\
\hline 37. & The teachers give clear examples & 2.66 \\
\hline 39. & The teachers get angry in class & 2.88 \\
\hline 40. & The teachers are well prepared for their classes & 2.70 \\
\hline 50. & The students irritate the teachers & 2.67 \\
\hline & Obtained Score & 31.3 \\
\hline
\end{tabular}

Source: The authors.

According to the students' perceptions, the activity is significant for medical training (2.80), provides adequate preparation for the profession (2.51) and promotes the development of skills for interpersonal relationships (2.64) and for problem-solving (2.55). There is a continuity of learning between the

$4 \mid$\begin{tabular}{l|l} 
REVISTA BRASILEIRA DE EDUCAÇÃO MÉDICA \\
\hline 44 (4) : e143; 2020
\end{tabular} 
academic semesters (2.15) and confidence in the semester approval by the majority (2.93). The total score in this dimension was 19.73 of a maximum of 32. According to the established criteria, the students' perception for the dimension "perception of academic results" was "positive".

Table 4 shows the average scores of the items for the dimension "perception of the general environment". The scores for items 17 and

\section{Table 3}

\begin{tabular}{|c|c|c|}
\hline \multirow{2}{*}{\multicolumn{3}{|c|}{$\begin{array}{c}\text { Table } 3 \\
\text { Score of items in the "Perception of Academic Re } \\
\text { of the DREEM questionnaire }\end{array}$}} \\
\hline & & \\
\hline Order & Item & Score \\
\hline 5. & $\begin{array}{l}\text { Learning strategies which worked for me before } \\
\text { continue to work for me now }\end{array}$ & 2.12 \\
\hline 10. & I am confident about passing this semester & 2.93 \\
\hline 21. & I feel I am being well prepared for my profession & 2.51 \\
\hline 26. & $\begin{array}{l}\text { Last semester's work has been a good preparation } \\
\text { for this semester's work }\end{array}$ & 2.15 \\
\hline 27. & I am able to memorize all I need & 2.03 \\
\hline 31. & I have learned a lot about empathy in my profession & 2.64 \\
\hline 41. & $\begin{array}{c}\text { My problem-solving skills are being well } \\
\text { developed here }\end{array}$ & 2.55 \\
\hline \multirow[t]{2}{*}{45.} & $\begin{array}{l}\text { Much of what I have to learn seems relevant to a } \\
\text { career in Medicine }\end{array}$ & 2.80 \\
\hline & Obtained Score & 19.73 \\
\hline
\end{tabular}

Source: The authors.

Table 4

Score of items in the "Perception of the General Environment" dimension of the DREEM questionnaire

\begin{tabular}{|c|c|c|}
\hline Order & Item & Score \\
\hline 11. & $\begin{array}{l}\text { The atmosphere } t \text { is relaxed during the ward } \\
\text { teaching }\end{array}$ & 2.35 \\
\hline 12. & This activity is well timetabled & 2.22 \\
\hline 17. & Cheating is problem in this activity & 2.98 \\
\hline 23. & $\begin{array}{l}\text { The atmosphere is relaxed during opening session } \\
\text { tutorial }\end{array}$ & 2.87 \\
\hline 30. & $\begin{array}{l}\text { There are opportunities for me to develop } \\
\text { interpersonal skills }\end{array}$ & 2.84 \\
\hline 33. & I feel comfortable in class socially & 2.51 \\
\hline 34. & The atmosphere is quiet during closing session tutorial & 2.76 \\
\hline 35. & I find the experience disappointing & 2.4 \\
\hline 36. & I am able to concentrate well & 2.55 \\
\hline 42. & $\begin{array}{c}\text { The enjoyment outweighs the stress of studying } \\
\text { medicine }\end{array}$ & 2.23 \\
\hline 43. & The atmosphere motivates me as a learner & 2.21 \\
\hline \multirow[t]{2}{*}{49.} & I feel able to ask the questions I want & 2.71 \\
\hline & Obtained Score & 30.63 \\
\hline
\end{tabular}

Source: The authors.
35 were reversed. According to the established criteria, the students' perception was "satisfactory" for all items of this dimension. It is worth mentioning the fact that the activity takes place in a quiet environment in the practice scenarios (2.35), in the opening (2.87) and closing of the cases (2.76), providing satisfaction (2.23) and stimulating the learning (2.21) and the practice of interpersonal relationships (2.84). Students feel comfortable (2.51) and feel free to clarify their doubts (2.71). The total score in this dimension was 30.63 of a maximum of 48 . According to the established criteria, the students' perception of the dimension "perception of the general environment" was "positive".

Table 5 shows the average scores of the items for the dimension "perception of social relationships". The score for item 4 was inverted. According to the established criteria, the students' perception was "satisfactory" for most items of this dimension, except for items 3 and 14, of which perception was "unsatisfactory". Among the positive aspects, good housing conditions (3.47), social life (2.69) and friendships established at Medical School (3.28) deserve to be highlighted. Some aspects suggested attention and improvements, such as the desire for a support good program for stressed students $(0.69)$ and greater stimulation for the development of the activity (1.42). The total score in this dimension was 17.05 of a maximum of 28 . According to the established criteria, the students' perception of the "perception of social relationships" dimension was "more positive than negative".

The total score of responses to the DREEM questionnaire was 124.31, corresponding to $62.15 \%$ of the maximum score of 200 points. According to the established criteria, the students' perception of this activity was "more positive than negative". The internal consistency of the responses to the instrument analyzed using Cronbach's alpha was 0.92 .

\section{DISCUSSION}

The National Curricular Guidelines (NCG) predict the inclusion of medical students in professional practice environments in the Brazilian Unified Health System (SUS, Sistema Único de Saúde) since the beginning of the course ${ }^{20}$. In the first years, many clinical clerkships are developed in PHC environments, a learning space shared by other courses in the health area, such as nursing, physiotherapy, and pharmacy. Associated to that, in

\begin{tabular}{|c|c|c|}
\hline \multicolumn{3}{|c|}{$\begin{array}{c}\text { Table } 5 \\
\text { Score of items in the "Perception of Social Relations" dimension of } \\
\text { the DREEM questionnaire }\end{array}$} \\
\hline Order & Item & Score \\
\hline 3. & $\begin{array}{c}\text { There is a good support system for students who } \\
\text { get stressed }\end{array}$ & 0.69 \\
\hline 4. & I am too tired to enjoy this activity & 2.05 \\
\hline 14. & I rarely bored on this activity & 1.42 \\
\hline 15. & I have good friends in this school & 3.28 \\
\hline 19. & My social life is good & 2.69 \\
\hline 28. & I seldom feel lonely & 2.29 \\
\hline 46. & My accommodation is pleasant & 3.47 \\
\hline & Obtained Score & 17.05 \\
\hline
\end{tabular}

Source: The authors. 
the last 20 years, the number of undergraduate medical courses in Brazil has more than tripled, from 113 schools at the end of the $20^{\text {th }}$ century to 323 courses in $2018^{21}$. This increase in the number of medical schools and in the number of students generated pressure on all learning spaces in the Unified Health System. In order to rebalance this relationship in favor of qualified training, it is necessary to incorporate more effective learning methodologies based on the practice in these clerkships, such as the $\mathrm{PBL}^{8}$. Faced with these challenges, the UNAERP Medical Course decided to adopt the Clinical PBL in PHC as a learning methodology based on practice in the BHUs and FHUs.

Since the 2000s, PBL has been used as a preferred teaching methodology in many undergraduate medical courses in Brazil and worldwide ${ }^{22,23}$. In most of these curricula, this strategy is used in the pre-clinical or preinternship phase and is aimed at developing the cognitive domain of medical skills ${ }^{24-26}$. When appropriately developed, the PBL provides the student with a deeper understanding of the underlying causes of physiological and pathophysiological phenomena, in addition to promoting the development of communication skills, clinical reasoning and teamwork ${ }^{27,28}$. According to learning theories, the acquisition of knowledge in PBL occurs through a similar way to that of clinical clerkships, both in terms of self-learning and in terms of information processing and collaborative learning ${ }^{23}$. In the PBL, the problem situation or "trigger element" promotes the mobilization of prior knowledge and critical reasoning to solve it through group discussion. Knowledge gaps are identified and after a self-directed study the problem is revisited, with the advantage of more in-depth knowledge $e^{23,24}$. All of these stages mirror the clinical learning that occurs from experiencing real practical cases and, therefore, the application of PBL in clinical clerkships would follow a natural path ${ }^{6}$. Moreover, the main resources necessary for the implementation of the PBL are already available in the clinical settings, including the clinical cases that serve as triggers, the supervisors who can act as facilitators and the small groups that go through the clerkship stages ${ }^{29}$.

Despite the advantages attributed to the use of clinical cases, it is notable that PBL is almost always a method restricted to classrooms and fictitious cases, with little experience reported in the literature on its application for discussing real clinical cases of practice 6 . Some studies have found favorable perceptions of medical students in relation to the Clinical PBL applied to bedside discussions ${ }^{6}$. However, regarding its application in PHC, we still have no reports in the literature and this work originally reports on this experience. In a systematic review carried out in 2007, only five good quality articles were found portraying the use of PBL in clinical education in undergraduate courses in the health area $^{30}$. The comparison between the results of these studies was hindered by the heterogeneity of designs and outcomes. The main reasons attributed to the paucity of the use of PBL in clinical settings were the lack of preparation and the lack of knowledge of the basic principles of this methodology by the preceptors and supervisors of the clinical clerkships. Given the lack of experience and security for using this method, clinical supervisors tend to abandon the facilitating model and revert to traditional teacher-centered teaching methods ${ }^{30}$.

The clinical PBL model in PHC implemented in the UNAERP Medical Course, was created based on the accumulated experience of more than 15 years with the use of this methodology by the faculty. We can cite as an example the incorporation of pre-tests at the beginning of the closing session, which in our previous experience had produced favorable educational impacts ${ }^{31}$. The initially proposed model was validated and incorporated suggestions from teachers, students, managers, and health professionals. Prior to the start of activities, all teachers involved were trained in the PBL methodology. During the training program, teachers participated as observers of PBL tutoring sessions and then clarified their doubts with more experienced facilitators. The importance of teacher training in the implementation of new educational interventions has already been described by several authors ${ }^{32}$.

The evaluation of students' perceptions on this activity was carried out using the validated version of the DREEM instrument in Portuguese ${ }^{11}$. This is an internationally recognized instrument, used to assess the perceptions and degree of satisfaction of medical students about new educational interventions, as was the case with clinical $\mathrm{PBL}^{16}$. The instrument corresponds to a questionnaire of 50 items distributed into five domains, which requires a long period of attention to produce conscious responses, making its completion sometimes exhausting and wearying. To verify the students' degree of commitment when completing the instrument, there are nine inverted items, where the positive perception will be given by disagreement instead of agreement. Since the average score of these items did not reflect discrepancies regarding the response in relation to the other items of the instrument, it must be assumed that there was not a significant degree of unconscious responses for most respondents.

There was great support from the student body for this work, considering the number of respondents to the questionnaire, which corresponded to $78 \%$ of students enrolled between the first and seventh semesters of the UNAERP Medical Course. It is a high rate of respondents, both in absolute terms and in relative terms. Other studies have also shown high adherence by medical students to questionnaires on the perception of course activities ${ }^{12,33,34}$. The mean age of the participants is compatible with the first three years of the course and the predominance of female students follows a national trend for medical courses. The greater number of participants in the first two semesters probably reflects the increase in the number of vacancies for the UNAERP Medical Course from January 2017, increasing from 60 to 90 vacancies per semester.

The results of the instrument application showed that for the dimension "Perception of Learning", the activity was considered "more positive than negative", being identified as student-centered and promoting self-confidence through self-learning, where the students are encouraged to participate in group discussions. Self-learning and collaborative learning constitute knowledge acquisition processes present both in $\mathrm{PBL}$ and in learning from practice ${ }^{23}$. In Clinical PBL, this learning occurs in a more consistent and structured way".

In the "Perception of the Teachers" dimension, the activity was rated as "positive", with the profile, qualification and training of the faculty being recognized for its development. The qualification of the teaching staff to act in the teaching-learning process is pointed out as a crucial point for the success of curricular changes in medical schools ${ }^{32}$. In our research, the teaching staff responsible for the Clinical PBL in PHC consists of 18 teachers, including $12(66 \%)$ doctors and $6(33 \%)$ nurses who act as supervisors of activities in the practice environments (HV, BHUs and FHUs) and as facilitators of the opening and closing sessions of the Clinical PBL in the classroom. Among the doctors, there are two family doctors, two pediatricians, two general practitioners, two psychiatrists and four gynecologists. All teachers have great professional experience in PHC activities and have been properly trained in the application of 
clinical PBL, which probably justifies the high degree of satisfaction of students with this teaching staff. Student satisfaction with PBL seems to be greater when the facilitators are specialists and have more experience in their area of expertise ${ }^{6,35}$. In a previous study carried out at the UNAERP Medical Course, the perceptions of 252 students about the participation of expert and non-expert facilitators in the $\mathrm{PBL}^{35}$ sessions were evaluated. There was a clear preference for expert facilitators, who were associated with greater cognitive learning (95\%), better conduction of the learning process (93\%), easier identification of study objectives (87\%) and greater motivation for self-directed study (82\%). Similar results were also found in a study carried out by Macallan, Kent et al. ${ }^{6}$, using the Clinical PBL.

In the dimension "Perception of Academic Results", the activity was rated as "positive". In this dimension, the several positively evaluated items reflect the significant learning provided by clinical PBL. The activity was considered "relevant" for medical training, providing "adequate preparation for the profession" in terms of developing "interpersonal skills" and "problem-solving skills". Clinical PBL uses problem-based learning and formative assessment with feedback as a strategy for developing these skills. The use of clinical cases of patients treated by the students themselves and the application of the acquired knowledge in the construction of the care plan for the same patients produce significant and long-lasting learning ${ }^{36,37}$.

In the dimension "Perception of the General Environment", the students' evaluation was "positive", with emphasis on the fact that the activity takes place in a "peaceful and respectful environment", both in the classroom and in the practice environments, where students feel "comfortable and encouraged to clarify their doubts". Such aspects are unique attributes to active teaching methodologies centered on the student, as is the case of Clinical PBL. In this activity, teachers act as facilitators, allowing each student to freely express their ideas and perceptions about a certain subject in the opening session (brainstorming) and clarify their doubts with the facilitators at the end of the closing session. As all facilitators of the activity have great practical experience in PHC, they can also act as consultants at the end of the second session and help students in the construction of the care plan.

In the "Perception of Social Relations" dimension, the activity was rated as "more positive than negative". In this dimension, some evaluated items transcend the limits of a single activity and often reflect the students' personal conditions in relation to their colleagues and the medical course. It is possible that the good living conditions and social life reported by most respondents reflect the profile of most medical students in private institutions.

The students' perceptions about the Clinical PBL in PHC were "positive" in three dimensions and "more positive than negative" in two dimensions of the instrument and according to the general score, they were "more positive than negative", which shows the favorable impact of this educational intervention. The internal consistency of responses to the analyzed instrument using Cronbach's alpha was 0.92 , showing that the reliability of the results was high in this student sample ${ }^{19}$.

Other educational institutions that use active and student-centered methodologies, such as the PBL, also showed positive perceptions of students after the application of the DREEM ${ }^{38}$ questionnaire and the activities with this profile tend to be better evaluated when compared to traditional teaching activities, centered on the teacher and distributed in large discipline blocks ${ }^{39,40}$. In situations where student-centered teaching methodologies have been implemented in traditional curricula, there has been an increase in the questionnaire response scores after curricular changes $^{12}$. Several items of the DREEM Questionnaire incorporate new ideas and principles characteristic of active teaching and learning methodologies, such as the implementation of student-centered activities, the provision of feedback, continuing education, the encouragement of self-learning and the development of interpersonal skills. Therefore, innovative teaching and learning methods tend to be valued in relation to the others when assessed through this instrument ${ }^{39,40}$.

Some experiences with clinical PBL described in the literature have also found similar results to ours. In 2009, Macallan, Kent et al. evaluated the perceptions of 97 medical students about the use of PBL in pre-internship clinical clerkships, including psychiatry, pediatrics and gynecology ${ }^{6}$. Most students' perceptions were positive for the academic results. The real clinical cases were considered appropriate for the discussion and, from them, it was possible to identify gaps in knowledge and learning objectives that were aligned with the curricular structure of the course $e^{6}$. A negative aspect pointed out by the students in the study by Macallan, Kent et $\mathrm{al}^{6}$. was the loss of follow-up of patients whose cases were discussed in the opening session, due to the change in clerkships by the students after the closing sessions.

In our experience, we use clinical PBL in PHC clerkships, where students follow the same patients and visit the same families throughout the school semester, thus allowing the care plan developed in the closing session to be taken to the patient or the family after the appropriate discussion with the local health team. Thus, students act as liaisons between the university and the health service, bringing to the classroom the reports of treatments and HVs in the opening session and taking the care plan created in the closing session to the BHUs and FHUs. Therefore, this activity not only uses a student-centered teaching methodology (PBL), but also places the student in a central role in the production of care. In addition to acquiring more consistent and lasting knowledge from the provided care, medical students contribute to a more qualified care of patients and families, through care plans based on scientific bases that incorporate references from person-centered Medicine. Under a broader concept, we can consider that clinical PBL is a teaching strategy centered on the student and the patient.

In some dimensions of the applied questionnaire, items with "unsatisfactory" evaluation were observed, which aroused the attention of teachers and managers and served as the basis for changes and adjustments to the activity structure. In the "learning perception" dimension, according to the respondents' opinions, the activity is not always stimulating, and the time allocated to it is not always well spent. In clinical PBL, the quality of the discussion depends largely on the quality of the presented reports. Superficial or incomplete reports generate little challenging and discouraging discussions. In view of these perceptions, the quality of the case reports started to be scored and became one of the components of the activity assessment. After this adjustment, there was a noticeable improvement in the quality of reports and student participation in discussions.

In the "perception of social relationships" dimension, the longing for a good program to support stressed students was identified as a point of dissatisfaction. It is known the fact that the overload of activities and medical school demands constitute an emotional stress factor for

REVISTA BRASILEIRA DE EDUCAÇ̃̃o MÉDICA

$744(4):$ el $143 ; 2020$ 
students $^{41}$. Faced with the knowledge of these students' expectations, in 2018 a psychological support service was established for all students in the UNAERP Medical Course, which was supported by professors from the Psychology course.

This study presents as a limitation the application of the DREEM questionnaire only after the implementation of the Clinical PBL in PHC. However, the percentage of respondents was high, the reliability of the instrument application was satisfactory, and the results showed a clear positive perception of students in relation to most of the assessed items, which demonstrates the wide acceptance of Clinical PBL by the student body.

This investigation sought to evaluate the use of Clinical PBL applied to $\mathrm{PHC}$ as an effective pedagogical option considering the overload of medical students in the BHUs and FHUs, and the need for more consistent learning based on the treated cases. According to our results, we concluded that Clinical PBL is a teaching strategy that is well-accepted by the students, enhances learning from practice and qualifies care. We believe that the topic addressed herein will be of great importance for health professionals, teachers and managers who need to deal with the challenges of medical education in increasingly scarce and overburdened health care settings daily.

\section{ACKNOWLEDGMENTS}

We would like to thank the management, the faculties, and students of the UNAERP Medical Course, without whom this work would not have been be possible.

\section{REFERENCES}

1. Bate E, Hommes J, Duvivier R, Taylor DC. Problem-based learning (PBL): getting the most out of your students - their roles and responsibilities: AMEE Guide no 84. Med Teach. 2014;36(1):1-12.

2. Neufeld VR, Barrows HS. The "McMaster Philosophy": an approach to medical education. J Med Educ. 1974;49(11):1040-50.

3. Barrows HS, Tamblyn RM. Problem-based learning: an approach to medical education. New York: Springer; 1980.

4. Barrows HS. Problem-solving learning. Med Educ. 1980;14(3):242-3.

5. Schmidt HG. Problem-based learning: rationale and description. Med Educ. 1983;17(1):11-6.

6. Macallan DC, Kent A, Holmes SC, Farmer EA, McCrorie P. A model of clinical problem-based learning for clinical attachments in medicine. Med Educ. 2009;43(8):799-807.

7. Taylor D, Miflin B. Problem-based learning: where are we now? Med Teach. 2008;30(8):742-63.

8. Diemers AD, van de Wiel MW, Scherpbier AJ, Baarveld F, Dolmans DH. Diagnostic reasoning and underlying knowledge of students with preclinical patient contacts in PBL. Med Educ. 2015;49(12):1229-38.

9. Romao GS, Bestetti RB, Couto LB. Problem-based learning in primary care at University of Ribeirao Preto (UNAERP) in Brazil. Adv Med Educ Pract. 2018;9:27-30.

10. Bestetti RB, Couto LB, Romao GS, Araujo GT, Restini CB. Contextual considerations in implementing problem-based learning approaches in a Brazilian medical curriculum: the UNAERP experience. Med Educ Online. 2014;19:24366.

11. Vieira JE, Nunes MPT, Martins MA. Directing student response to early patient contact by questionnaire. Med Educ. 2003;37(2):119-25.

12. Riquelme A, Oporto M, Oporto J, Méndez JI, Viviani P, Salech F, et al. Measuring students' perceptions of the educational climate of the new curriculum at the pontificia universidad catØlica de chile: Performance of the spanish translation of the Dundee Ready Education Environment Measure (DREEM). Educ Health (Abingdon). 2009;22(1):112.

13. Roff S, McAleer S, Harden RM, Al-Qahtani M, Ahmed AU, Deza H, et al. Development and validation of the Dundee Ready Education Environment Measure (DREEM). Med Teach. 1997;19(4):295-9.

14. Jakobsson U, Danielsen N, Edgren G. Psychometric evaluation of the Dundee Ready Educational Environment Measure: Swedish version. Med Teach. 2011;33(5):e267-e274.

15. Hammond SM, O'Rourke M, Kelly M, Bennett D, O'Flynn S. A psychometric appraisal of the DREEM. BMC Med Educ. 2012;12(1):2-5.

16. Swift L, Miles S, Leinster SJ. The analysis and reporting of the Dundee Ready Education Environment Measure (DREEM): some informed guidelines for evaluators. Creat Educ. 2013;4(05):340-7.

17. Jiffry MT, McAleer S, Fernando S, Marasinghe RB. Using the DREEM questionnaire to gather baseline information on an evolving medical school in Sri Lanka. Med Teach. 2005;27(4):348-52.

18. Edgren G, Haffling AC, Jakobsson U, McAleer S, Danielsen N. Comparing the educational environment (as measured by DREEM) at two different stages of curriculum reform. Med Teach. 2010;32(6):e233-8.

19. Tavakol M, Dennick R. Making sense of Cronbach's alpha. Int J Med Educ. 2011;2:53-5.

20. Brasil. Resolução CNE/CES no 3, de 20 de junho de 2014. Institui as Diretrizes Curriculares Nacionais do Curso de Graduação em Medicina e dá outras providências. Diário Oficial da União, Brasília; 23 jun. 2014; Seção 1, p. 8-11.

21. de Oliveira BLCA, Lima SF, Pereira MUL, Pereira Júnior GA. Evolução, distribuição e expansão dos cursos de Medicina no Brasil (1808-2018). Trab Educ Saúde. 2019;17(1):e0018317.

22. Jolly B. Problem-based Learning. Med Educ. 2006;40:494-5.

23. Albanese MA. Problem-based learning. Association for the Study of Medical Education [Edinburgh]; 2007.

24. Barrows HS. How to design a problem-based curriculum for the preclinical years. New York: Springer; 1985.

25. de Leng BA, Dolmans DH, Muijtjens AM, van der Vleuten CP. Student perceptions of a virtual learning environment for a problembased learning undergraduate medical curriculum. Med Educ. 2006;40(6):568-75.

26. Mamede S, Schmidt HG, Norman GR. Innovations in problem-based learning: what can we learn from recent studies? Adv Health Sci Educ Theory Pract. 2006;11(4):403-22.

27. Norman GR, Schmidt HG. The psychological basis of problem-based learning: a review of the evidence. Acad Med. 1992;67(9):557-65.

28. Gresham CL, Philp JR. Problem-based learning in clinical medicine. Teach Learn Med. 1996;8(2):111-5.

29. Dolmans DH, De Grave W, Wolfhagen IH, van der Vleuten CP. Problem-based learning: future challenges for educational practice and research. Med Educ. 2005;39(7):732-41.

30. Williams SM, Beattie HJ. Problem based learning in the clinical setting: a systematic review. Nurse Educ Today. 2008;28(2):146-54. 
31. Bestetti RB, Couto LB, Restini CB, Faria Júnior M, Romao GS. Assessment test before the reporting phase of tutorial session in problem-based learning. Adv Med Educ Pract. 2017;8:181-7.

32. Hitchcock MA, Mylona ZH. Teaching faculty to conduct problembased learning. Teach Learn Med. 2000;12(1):52-7.

33. Demiroren M, Palaoglu O, Kemahli S, Ozyurda F, Ayhan IH. Perceptions of students in different phases of medical education of educational environment: Ankara University Faculty of Medicine. Med Educ Online. 2008;13:8 [Apenas uma página? sim].

34. Shankar PR, Dubey AK, Balasubramanium R. Students' perception of the learning environment at Xavier University School of Medicine, Aruba. J Educ Eval Health Prof. 2013;10:8-12.

35. Couto LB, Bestetti RB, Restini CB, Faria Júnior M, Romao GS. Brazilian medical students' perceptions of expert versus non-expert facilitators in a (non) problem-based learning environment. Med Educ Online. 2015;20:26893.

36. Schmidt HG, Boshuizen HPA. On acquiring expertise in medicine. Educ Psychol Rev 1993;5(3):205-21.

37. Schmidt HG. Foundations of problem-based learning: some explanatory notes. Med Educ. 1993;27(5):422-32.

38. Dunne F, McAleer S, Roff S. Assessment of the undergraduate medical education environment in a large UK medical school. Health Educ J. 2006;65(2):149-58.

39. Al-Mohaimeed A. Perceptions of the educational environment of a new medical school, Saudi Arabia. Int J health Sci (Qassim). 2013;7(2):150-9
40. Kiran HS, Gowdappa BH. "DREEM" comes true-Students' perceptions of educational environment in an Indian medical school. J Postgrad Med. 2013;59(4):300-5.

41. Pacheco JP, Giacomin HT, Tam WW, Ribeiro TB, Arab C, Bezerra IM, et al. Mental health problems among medical students in Brazil: a systematic review and meta-analysis. Braz J Psychiatry. 2017;39(4):369-78.

\section{AUTHORS ‘CONTRIBUTION}

All authors participated consistently in the study conception, design, data analysis and interpretation, as well as in the writing of this manuscript, assuming the authorship and public responsibility for the content of this article.

\section{CONFLICTS OF INTEREST}

The authors declare no conflicts of interest. This project has not received external funding.

\section{ADDRESS FOR CORRESPONDENCE}

Gustavo Salata Romão. Avenida Costábile Romano, 2201, Ribeirânia, Ribeirão Preto, SP, Brasil. CEP: 14096-900.

E-mail: gsalata@uol.com.br 